\title{
Molecular changes of ferric oxide bound soil humus during the decomposition of maize straw
}

\author{
Xiangyun Song, Lianqing Li, Xuhui Zhang, Jufeng Zheng, Jinwei Zheng, Qaiser Hussain and Genxing Pan*
}

\begin{abstract}
Background: The mechanism of organic carbon sequestration in different genesis of paddy soils has not been well understood. A 6-month incubation experiment, adding maize straw, was performed in three different genesis of paddy soils and an uncultivated marsh soil. Fourier transform infrared (FTIR) spectroscopy was used to investigate the characteristics of Fe/Al bound organic carbon (Fe/Al-OC) extracted with a mixed solution of $0.1 \mathrm{M} \mathrm{NaOH}$ and $\mathrm{Na}_{4} \mathrm{P}_{2} \mathrm{O}_{7}$ from soils.
\end{abstract}

Results: The function groups of Fe/Al-OC such as phenol-C, amide-C, and $\mathrm{C}-\mathrm{O}$ groups of polysaccharides were demonstrated by FTIR spectroscopy. Compared to control treatment, the proportion of phenol-C of Fe/Al-OC added maize straw increased with time, but the $\mathrm{C}-\mathrm{O}$ groups of polysaccharides decreased.

Conclusions: These results indicate that polysaccharide groups of Fe/Al-OC mainly contribute to the sequestration of Fe/AI-OC during the primary decomposition stage of maize straw, and the phenol group was stable in different genesis of paddy soils. Both of the polysaccharides and phenol groups were important to $C$ sequestration in paddy soils and marsh soil.

Keywords: Fourier transform infrared (FTIR) spectroscopy, Soil carbon sequestration, Paddy soil, Fe/Al bound organic carbon, Hydrophobic substance

\section{Background}

The carbon cycling in soils is a critical process of earth surface system closely related to global climate change, and the interest in agricultural soil as global carbon storage has increased in recent years $[1,2]$. Organic matter (OM) mineralization in soil may be reduced through increasing organic carbon $(\mathrm{OC})$ sequestration into hydrophobic domains in humic material of comfortable composition [3]. The content of $\mathrm{OC}$ was high in paddy soil than in dry land and the mineralization rate of $\mathrm{OC}$ was lower in anaerobic culture rather than aerobic culture in paddy soil [4].

In addition, the $\mathrm{OC}$ sequestration in China's rice paddies related to chemical binding of iron or aluminum [5]. A number of reports relate to the return of crop residue into field [6-11]. However, the mechanism of carbon sequestration

*Correspondence: pangenxing@aliyun.com

Institute of Resource, Ecosystem and Environment of Agriculture, Nanjing

Agricultural University, Nanjing 210095, People's Republic of China of crop residue in different origin of paddy soils is not clear until now. The composition and nature of humus derived from different origin paddy soils are various [12]. Moreover, humified OM and the reduction of their microbial mineralization could protect the labile organic compounds effectively in soil [13]. The microbial and enzyme activities are seriously changed [4], and the formation of soil humus is considerably different during decomposition of crop residue [8]. With the decomposition of maize residue, the characteristic of soil humus is various $[14,15]$. Not only Solid-state ${ }^{13} \mathrm{C}$ nuclear magnetic resonance (NMR) spectroscopy can be used to study soil organic matter (SOM) [16-18], but also Fourier transform infrared (FTIR) spectroscopy is also a useful technique in distinguishing the main chemical functional groups of SOM, such as carbohydrates, lignin, cellulose, fats, and/or lipids and proteinaceous compounds [19]. The direct information of functional groups in SOM fraction could be investigated by FTIR spectroscopy [20]. 
Only a few studies on the mechanisms of SOM accumulation in representative paddy soils are documented $[19,21]$. Are the characteristics of organic fractions of paddy soils and uncultivated marsh soil similar in the course of carbon sequestration? Which functional groups favor soil carbon sequestration in paddy soils?

The objective of this work is to investigate the characteristics of $\mathrm{Fe} / \mathrm{Al}$ bound organic carbon $(\mathrm{Fe} / \mathrm{Al}-\mathrm{OC}$ ) in different genesis of paddy soils by FTIR spectra.

\section{Methods}

\section{Soils}

Three representative paddy soils and an uncultivated marsh soil were used in this study. The paddy soils (Hydrgric Anthrosols) included: First, Soil TP, developed from clayey lacustrine deposits in the Tai-Lake plain, from Wu Jiang County, Jiangsu Province; second, Soil RP, derived from red earth in the rolling red soil area, from Jin Xian Country, Jiangxi Province; and third, Soil PP, formed on Jurassic purple shale and sandstone, from the Sichuan purple sandstone rolling area, Chongqing Municipality. Forth, Soil MS, a marsh soil Calcaric Fluvisol, from Shengjin Wetland, Chizhou City, Anhui Province. The marsh soil was used for comparison with paddy soil because it was the precedent soil for rice paddies in the lower reaches of Yangtze River valley. The soil samples were taken from topsoil at $0-15 \mathrm{~cm}$ depth in early spring of 2008 and were three field replicates.

Coarse organic matters (free roots and plant debris) and stones in surface samples $(0-15 \mathrm{~cm})$ of these soils were picked out with tweezers after sampling. The samples were sieved $(<2 \mathrm{~mm})$ and stored at $20^{\circ} \mathrm{C}$ for 10 days before incubation. It was used to minimize the variations which were caused by microbial activity at different temperatures.

\section{Maize residue}

Maize residue was used as organic amendment to the soil. Maize straw was collected from a maize farm and air-dried at room temperature. The kernels and roots were removed. In addition, other parts of maize straw were cut to small pieces and passed through a $0.42 \mathrm{~mm}$ sieve and were oven-dried at $60{ }^{\circ} \mathrm{C}$. The maize residue contained 438 and $6.81 \mathrm{~g} \mathrm{~N} \mathrm{~kg}^{-1}$ on dry base.

\section{Laboratory incubation}

The field triplicate soils were mixed before incubation in order to keep the same type of soils in a similar condition. The maize residues were used as $C$ input to soils and mixed with soils in a percentage of $6 \%$ (dry base). The $\mathrm{C} / \mathrm{N}$ ratio of the residual/soils mixture was adjusted to 20 using a solution of $\left(\mathrm{NH}_{4}\right)_{2} \mathrm{SO}_{4}$. The mixtures were weight into plastic containers and the water holding capacity (WHC) is adjusted to $60 \%$. Then, they were incubated in an incubator (LRH-250-S, Medicine Machinery Co. Ltd., Guangdong, China) under $25^{\circ} \mathrm{C}$ in triplicate. The distilled water was added into samples per $48 \mathrm{~h}$ in order to keep the WHC at $60 \%$. In addition, the control treatments without maize residuals were also incubated at the same time. Incubations were carried out for 30, 90, and 180 days.

\section{Extraction of iron/aluminum bound fractions}

The $\mathrm{Ca}$ bound organic carbon $(\mathrm{Ca}-\mathrm{OC})$ and iron/aluminum bound organic carbon ( $\mathrm{Fe} / \mathrm{Al}-\mathrm{OC}$ ) were extracted using $0.5 \mathrm{M} \mathrm{Na}_{2} \mathrm{SO}_{4}$ and a mixed solution of $0.1 \mathrm{M} \mathrm{NaOH}$ and $\mathrm{Na}_{4} \mathrm{P}_{2} \mathrm{O}_{7}$ following the outline of $\mathrm{Xu}$ and Yuan [22]. The samples were extracted by shaking for $1 \mathrm{~h}$ with a 1:10 $\mathrm{w} / \mathrm{v}$ of $0.5 \mathrm{M} \mathrm{Na}_{2} \mathrm{SO}_{4}$ solution and then the mixture was remained for $24 \mathrm{~h}$. The mixture was centrifuged approximately at $1780 \mathrm{~g}$ for $15 \mathrm{~min}$ at $20{ }^{\circ} \mathrm{C}$ in order to obtain the Ca-OC. The supernatants were filtered $(0.22 \mu \mathrm{m})$ in a $250 \mathrm{~mL}$ plastic bottle after centrifuging, and the residue was washed with a $1 \% \mathrm{Na}_{2} \mathrm{SO}_{4}$ solution. The procedure above was repeated in triplicate, and the supernatants were combined. Then, it was centrifuged at approximately $7150 \mathrm{~g}$ for $20 \mathrm{~min}$ at $20{ }^{\circ} \mathrm{C}$ and filtered $(0.22 \mu \mathrm{m})$ into a volumetric flask.

The residue was washed with distilled water and centrifuged at $7150 \mathrm{~g}$ for $20 \mathrm{~min}$ at $20{ }^{\circ} \mathrm{C}$ in triplicates after extracting $\mathrm{Ca}-\mathrm{OC}$. The residue was subsequently extracted by shaking for $1 \mathrm{~h}$ with a $1: 10 \mathrm{w} / \mathrm{v}$ of $0.1 \mathrm{~mol} / \mathrm{L}$ $\mathrm{NaOH}$ and $\mathrm{Na}_{4} \mathrm{P}_{2} \mathrm{O}_{7}(1: 1 \mathrm{v} / \mathrm{v}, \mathrm{pH}=13.0)$ solution and then the mixture was remained for $24 \mathrm{~h}$. The mixture was centrifuged at approximately $1780 \mathrm{~g}$ for $15 \mathrm{~min}$ at $20{ }^{\circ} \mathrm{C}$ in order to obtain the Fe/Al-OC. After centrifuging, the supernatants were transferred into a $250 \mathrm{~mL}$ plastic bottle by filtering $(0.22 \mu \mathrm{m})$. The residue was the humin fraction. The steps above were also repeated in triplicate, and then the supernatants were transferred in the same bottle. All the supernatants were centrifuged at approximately $7150 \mathrm{~g}$ for $20 \mathrm{~min}$ at $20{ }^{\circ} \mathrm{C}$ and filtered $(0.22 \mu \mathrm{m})$ into a volumetric flask. The Fe/Al-OC was dialyzed against deionized water, and freeze-dried.

\section{Soil analysis \\ Basic properties}

Basic properties are provided in Table 1 . Soil $\mathrm{pH}$ was measured with a composite electrode under a 1:2.5 soil to water ratio. Organic carbon was determined by digestion with $0.4 \mathrm{~mol} / \mathrm{L}$ potassium dichromate and back titrating with $0.2 \mathrm{~mol} \mathrm{~L}^{-1}$ ferrous ammonium sulfate. Total $N$ was measured by kjeldahl method. The free iron oxide $\left(\mathrm{Fe}_{\mathrm{d}}\right)$ was extracted by a Dithionite-citrate system buffered with sodium bicarbonate (DCB) and was measured with atomic absorption spectrometer (AAS). Clay content was determined by pipette method. The cation exchange capacity (CEC) was measured by $\mathrm{NH}_{4} \mathrm{OAC}$ buffer [23]. 
Table 1 Physicochemical properties of the representative types of soils studied

\begin{tabular}{|c|c|c|c|c|c|c|c|c|}
\hline Soil types & $\operatorname{SOC}\left(\mathrm{g} \mathrm{kg}^{-1}\right)$ & $\mathrm{Fe}_{\mathrm{d}}^{\mathrm{a}}\left(\mathrm{g} \mathrm{kg}^{-1}\right)$ & Total N $\left(\mathrm{g} \mathrm{kg}^{-1}\right)$ & $\mathrm{C} / \mathrm{N}$ & Clay $\left(\mathrm{g} \mathrm{kg}^{-1}\right)$ & $\mathrm{CEC}^{\mathbf{b}}\left(\mathrm{Cmol} \mathrm{kg}^{-1}\right)$ & $\mathrm{pH}\left(\mathrm{H}_{2} \mathrm{O}\right)$ & $\begin{array}{l}\text { WHC } \\
\left(\mathrm{g} \mathrm{kg}^{-1}\right)\end{array}$ \\
\hline $\mathrm{TP}$ & 19.02 & 14.99 & 1.65 & 11.56 & 273.1 & 18.91 & 5.28 & 666 \\
\hline $\mathrm{RP}$ & 21.79 & 15.95 & 1.89 & 11.54 & 198.0 & 8.83 & 4.61 & 708 \\
\hline PP & 17.61 & 10.00 & 1.70 & 10.37 & 156.9 & 23.79 & 7.26 & 594 \\
\hline MS & 17.88 & 15.05 & 1.74 & 10.29 & 97.0 & 14.01 & 7.33 & 573 \\
\hline
\end{tabular}

The soils used in this study were three replicates and mixed before incubation in order to keep the same type of soils in a similar condition. TP Tai-Lake plain soil; RP red earth paddy soil; $P P$ purple paddy soil; $M S$ marsh soil

a Free ferric oxide

b Cation exchange capacity

c Water holding capacity

The yields of $\mathrm{Fe} / \mathrm{Al}-\mathrm{OC}$ extracted from soil without incubation (Fig. 1a) and soils incubated for 30, 90, and 180 days (Fig. 1b) were calculated by the percentages of dry weight of $\mathrm{Fe} / \mathrm{Al}-\mathrm{OC}$ in the weight of soils used in this study.

\section{FTIR spectroscopy analysis}

Spectral characterization of Fe/Al-OC samples was performed with a Bruker 66v/s FTIR spectrometer in the mid IR area from 4000 to $400 \mathrm{~cm}^{-1}$. Spectra were recorded with a resolution of $4 \mathrm{~cm}^{-1}$ and 128 scans per sample. The
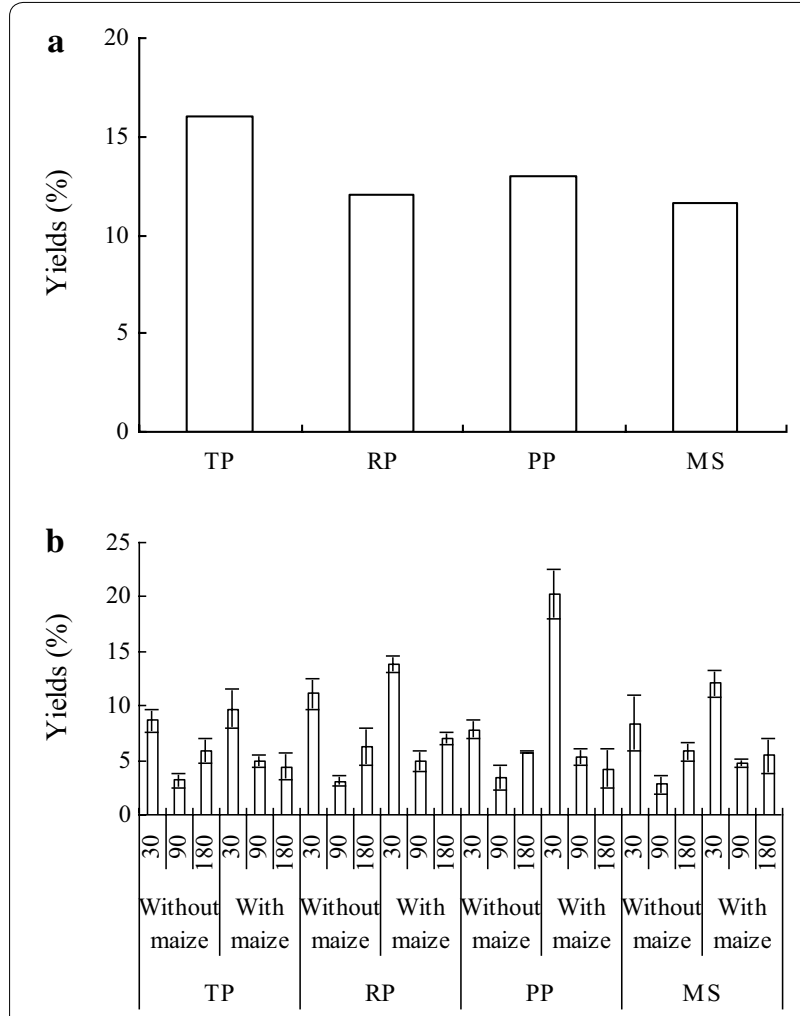

Fig. 1 The yield of Fe/Al-OC extracted from soils without incubation (a) and soils incubated for 30,90, and 180 days (b); TPTai-Lake plain soil; $R P$ red earth paddy soil; PP purple paddy soil; MS marsh soil; In figure $\mathbf{b}$ the results are mean $\pm \mathrm{SD}(n=3)$ background of ambient air was submitted. The spectrum was obtained on pellets, adding $1 \mathrm{mg}$ of lyophilized sample to $200 \mathrm{mg} \mathrm{KBr}$ and previously dried in an oven. The software used to analyze the data was OMNIC version 6.1 for Windows (Thermo Nicolet Instrument Corp. Madison, WI). Firstly, the mid-infrared spectroscopy was automatically baseline corrected and normalized. Then the area was integrated between the tangent of two trough points of the peak and the spectroscopy. The total area of peaks was calculated by adding each peak area. Finally, the percentage of each peak for total area of peaks was calculated.

\section{Results}

Organic carbon functional groups of $\mathrm{Fe} / \mathrm{Al}-\mathrm{OC}$

The spectral region was from 4000 to $400 \mathrm{~cm}^{-1}$, and automatic baseline correction was conducted. The map profiles were created for peak heights at 3500-3200, 1666, 1160, and $1110 \mathrm{~cm}^{-1}$ (Figs. 2, 3, 4, 5). The broad intense band at $3500-3200 \mathrm{~cm}^{-1}$, corresponded mainly to stretching vibrations of $\mathrm{H}$-bonded hydroxyl $(\mathrm{O}-\mathrm{H})$ groups of phenol, as well as traces of amine $(\mathrm{N}-\mathrm{H})$ stretch [19, 24-26]. The broad band near $1666 \mathrm{~cm}^{-1}$ was assigned primarily to $\mathrm{C}=\mathrm{O}$ of amide I $[19,27]$. The absorption at $1160 \mathrm{~cm}^{-1}$ attributed to $\mathrm{C}-\mathrm{O}$ band in both polyalcoholic and ether functional groups, such as those in oligo- and polysaccharide [3]. The strong band at about $1110 \mathrm{~cm}^{-1}$ could be attributed to $\mathrm{C}-\mathrm{O}$ stretching vibrations of polysaccharides [19, 28, 29] and/or possibly contributed from phosphate groups [30].

In this study, the areas of absorbance peaks of functional groups are shown in Tables 2, 3, 4, 5. The functional groups of $\mathrm{Fe} / \mathrm{Al}-\mathrm{OC}$ were demonstrated in FTIR spectra including phenols, amide polymers, and polysaccharide (Figs. 2, 3, 4, 5).

\section{Variation on the characteristics of Fe/Al-OC in different incubation stages}

Compared to $\mathrm{Fe} / \mathrm{Al}-\mathrm{OC}$ extracted from paddy soils and marsh soil without maize straw, the relative contents of 


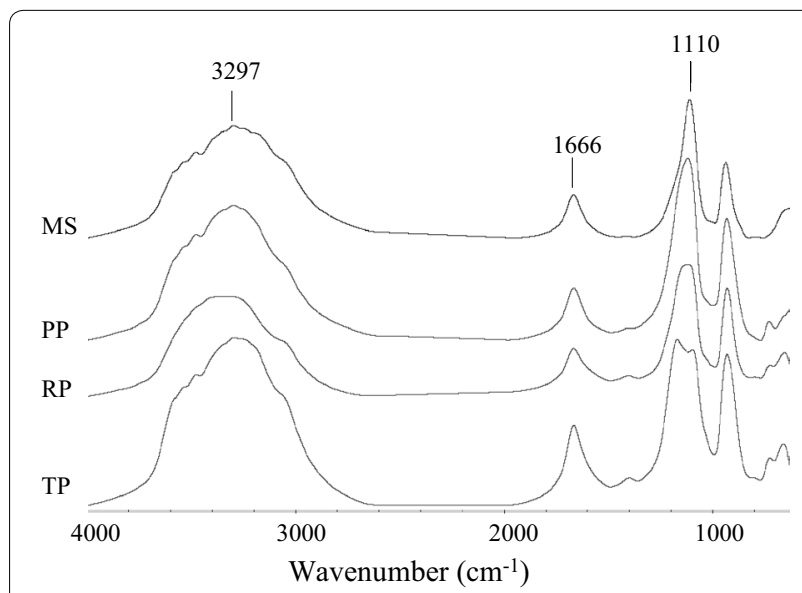

Fig. 2 FTIR spectroscopy of Fe/AI-OC extracted from original soils; TP Tai-Lake plain soil, RP red earth paddy soil, $P P$ purple paddy soil, MS marsh soil

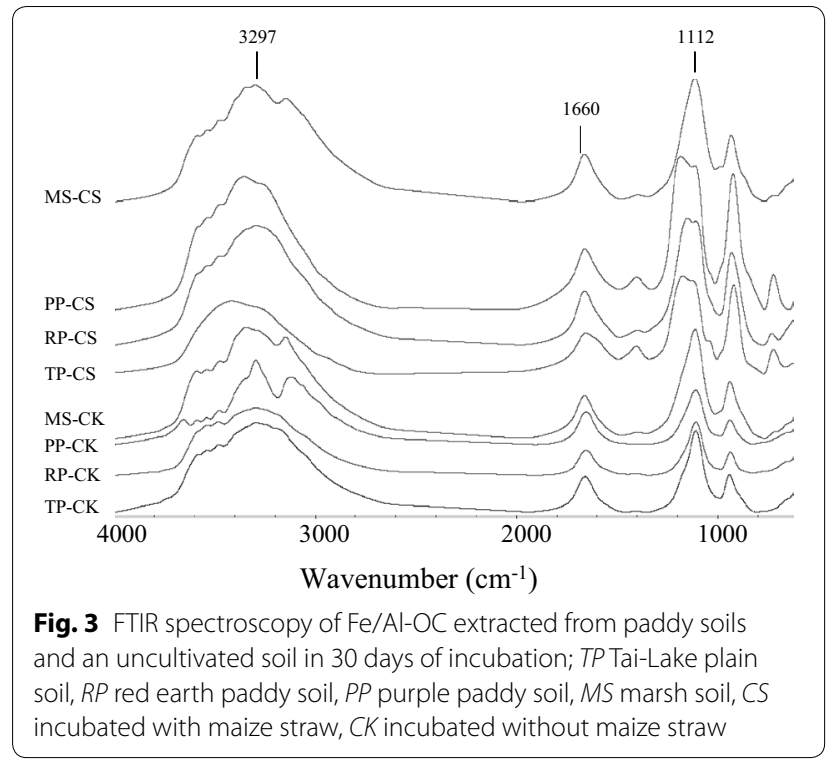

phenol-C of Fe/Al-OC extracted from soil TP, RP, PP, and MS with maize straw decreased by $12.70,8.12,8.53$, and $1.58 \%$ in 30 days of incubation, respectively. Moreover, the relative contents of polysaccharide- $\mathrm{C}$ of $\mathrm{Fe} /$ Al-OC extracted from soil TP, RP, PP, and MS increased by $11.49,6.85,9.40$, and $1.01 \%$, respectively. In addition, the proportions of amide- $\mathrm{C}$ of $\mathrm{Fe} / \mathrm{Al}-\mathrm{OC}$ extracted from soil TP, RP, and MS increased by $1.21,1.27$, and $6.85 \%$, but decreased by $0.87 \%$ in soil PP (Fig. 3; Table 3). These results showed that the relative content of polysaccharide groups increased in the primary stage of incubation with maize straw, and the amide groups were stable. However, the proportion of phenol groups of $\mathrm{Fe} / \mathrm{Al}-\mathrm{OC}$ extracted from paddy soils and marsh soil decreased.

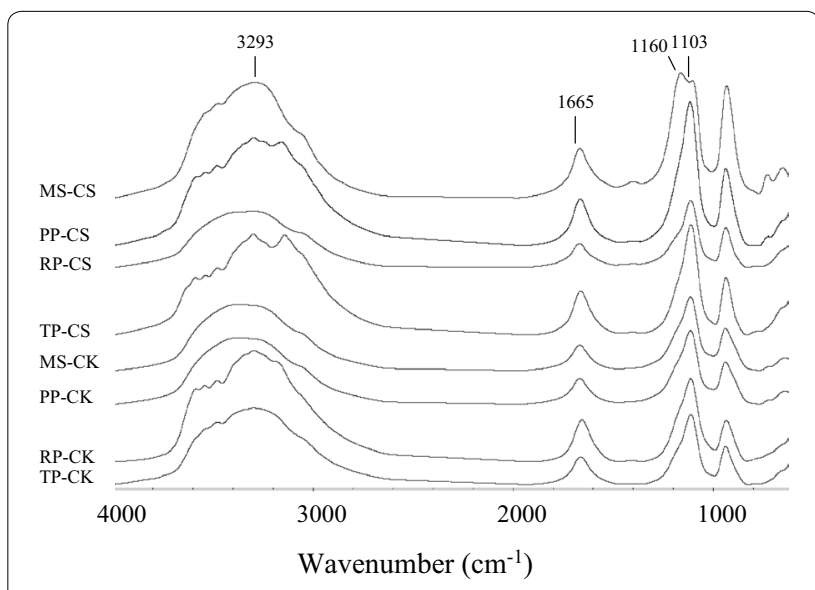

Fig. 4 FTIR spectroscopy of Fe/Al-OC extracted from paddy soils and an uncultivated soil in 90 days of incubation; TP Tai-Lake plain soil, $R P$ red earth paddy soil, $P P$ p purple paddy soil, MS marsh soil, CS incubated with maize straw, $C K$ incubated without maize straw

Compared to soils without maize straw, the proportion of phenol-C of Fe/Al-OC extracted from soil TP, RP, PP, and MS with maize straw decreased by $2.18,3.99$, 3.40 , and $2.71 \%$ in the incubation of 90 days, respectively. The proportion of polysaccharide- $\mathrm{C}$ of $\mathrm{Fe} / \mathrm{Al}-\mathrm{OC}$ extracted from soil TP, RP, PP, and MS with addition of maize straw increased by $1.75,4.05,3.27$, and $3.01 \%$, respectively. Moreover, the proportions of amide- $\mathrm{C}$ of $\mathrm{Fe} / \mathrm{Al}-\mathrm{OC}$ extracted from soil TP, RP, PP, and MS with maize straw increased by $0.43 \%$ and $0.13 \%$ in soil TP and PP, but decreased by 0.06 and $0.30 \%$ in soil RP and MS (Fig. 4; Table 4). These results showed that the relative content of polysaccharide groups increased in 90 days of incubation. However, the increase of polysaccharide groups was lower in 90 days of incubation than in 30 days of incubation in paddy soil, while it was higher than in 30 days of incubation in marsh soil. Moreover, the amide groups were also stable. The proportion of phenol groups of Fe/Al-OC extracted from paddy soils and marsh soil decreased too. Compared with marsh soil, it decreased much in marsh soil more than in paddy soils.

Compared to soils without maize straw, the proportions of phenol-C of Fe/Al-OC extracted from soil TP, RP, $\mathrm{PP}$, and MS with maize straw increased by $4.71,0.34,1.22$, and $2.70 \%$ in the incubation of 180 days, respectively. In addition the proportion of polysaccharide- $\mathrm{C}$ of $\mathrm{Fe} / \mathrm{Al}-\mathrm{OC}$ extracted from soil TP, RP, PP, and MS decreased by 3.27 , $0.56,1.80$, and $2.77 \%$, respectively. Relative contents of amide-C of Fe/Al-OC extracted from soil TP decreased by $1.44 \%$, but it increased by $0.22,0.59$, and $0.07 \%$ in Fe/ Al-OC extracted from soil RP, PP, and MS, respectively (Fig. 5; Table 5). 


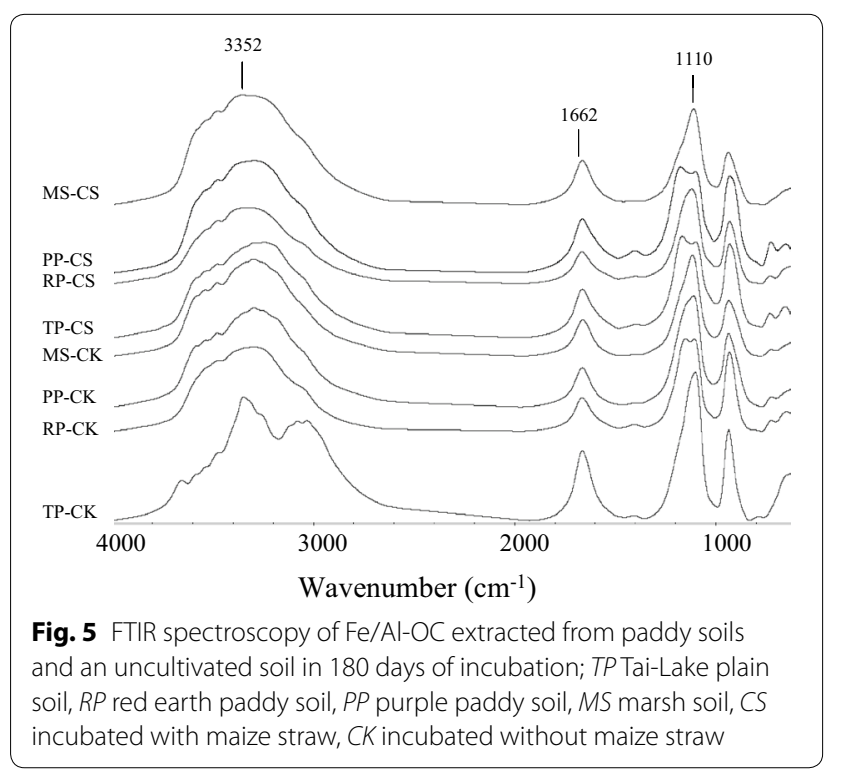

Table 2 Relative areas of the main absorption peaks of IR spectrum of $\mathrm{Fe} / \mathrm{Al}-\mathrm{OC}$ extracted from original soils (\%) (semi-quantitative)

\begin{tabular}{llll}
\hline Soil types & Phenol-C & Amide-C & Polysaccharide-C \\
\hline TP & 77.51 & 6.39 & 16.10 \\
RP & 74.43 & 6.07 & 19.50 \\
PP & 74.31 & 5.78 & 19.91 \\
MS & 78.16 & 6.22 & 15.62 \\
\hline
\end{tabular}

Table 3 Relative areas of main peaks of IR spectrum of Fe/Al-OC extracted from paddy soils and marsh soil after $\mathbf{3 0}$ days of incubation (\%) (semi-quantitative)

\begin{tabular}{lllll}
\hline $\begin{array}{l}\text { Soil } \\
\text { types }\end{array}$ & $\begin{array}{l}\text { Addition } \\
\text { of maize } \\
\text { straw (\%) }\end{array}$ & Phenol-C & Amide-C & Polysaccharide-C \\
\hline TP & 0 & 81.08 & 7.18 & 11.73 \\
RP & 0 & 82.79 & 6.44 & 10.77 \\
PP & 0 & 80.48 & 8.03 & 11.49 \\
MS & 0 & 79.47 & 7.09 & 13.44 \\
TP & 6 & 68.38 & 8.39 & 23.23 \\
RP & 6 & 74.67 & 7.71 & 17.62 \\
PP & 6 & 71.94 & 7.17 & 20.89 \\
MS & 6 & 77.89 & 7.66 & 14.45 \\
\hline
\end{tabular}

\section{Discussion}

Effect of phosphate and/or pyrophosphate on the bands of FTIR spectroscopy

The assignment of the absorption bands at about $1100 \mathrm{~cm}^{-1}$ was frequently assigned to alcoholic and
Table 4 Relative areas of main peaks of IR spectrum of Fe/AI-OC extracted from paddy soils and marsh soil after 90 days of incubation (\%) (semi-quantitative)

\begin{tabular}{lllll}
\hline $\begin{array}{l}\text { Soil } \\
\text { types }\end{array}$ & $\begin{array}{l}\text { Addition } \\
\text { of maize straw } \\
(\%)\end{array}$ & Phenol-C & Amide-C & Polysaccharide-C \\
\hline TP & 0 & 80.21 & 6.42 & 13.37 \\
RP & 0 & 81.52 & 6.58 & 11.90 \\
PP & 0 & 78.57 & 6.51 & 14.92 \\
MS & 0 & 78.65 & 6.52 & 14.83 \\
TP & 6 & 78.03 & 6.85 & 15.12 \\
RP & 6 & 77.53 & 6.53 & 15.94 \\
PP & 6 & 75.17 & 6.64 & 18.18 \\
MS & 6 & 75.95 & 6.22 & 17.84 \\
\hline
\end{tabular}

Table 5 Relative areas of main peaks of IR spectrum of Fe/AI-OC extracted from paddy soils and marsh soil after 180 days of incubation (\%) (semi-quantitative)

\begin{tabular}{lllll}
\hline $\begin{array}{l}\text { Soil } \\
\text { types }\end{array}$ & $\begin{array}{l}\text { Addition } \\
\text { of maize straw } \\
(\%)\end{array}$ & Phenol-C & Amide-C & Polysaccharide-C \\
\hline TP & 0 & 71.84 & 9.09 & 19.06 \\
RP & 0 & 74.60 & 6.56 & 18.84 \\
PP & 0 & 76.08 & 6.59 & 17.34 \\
MS & 0 & 77.89 & 6.82 & 15.29 \\
TP & 6 & 76.55 & 7.66 & 15.80 \\
RP & 6 & 74.94 & 6.78 & 18.28 \\
PP & 6 & 77.30 & 7.17 & 15.53 \\
MS & 6 & 80.59 & 6.89 & 12.52 \\
\hline
\end{tabular}

polysaccharide $\mathrm{C}-\mathrm{O}$ stretching or to vibrations of a $\mathrm{SiO}_{2}$ related impurity in humic substances [31]. However, it was noteworthy that the extraction itself was known as leading to incorporations of phosphate and/or pyrophosphate in the extracted organic matter. Francioso et al. [30] attributed the absorption bands at 1100 to $1000 \mathrm{~cm}^{-1}$ mainly to phosphate groups as a result of high concentration of total $\mathrm{P}$ in the humic substances extracted by $\mathrm{NaOH}$ plus pyrophosphate. Rulmont et al. [32] showed that the strongest absorbance band of orthophosphate was near $1050 \mathrm{~cm}^{-1}$. In this study, the extraction condition was the same, thus the effect of phosphate could be ignored.

Stability of phenol and polysaccharides groups of Fe/AI-OC In this study, the results of FTIR spectroscopy showed that the proportion of polysaccharide increased in the primary stage, and then it decreased due to the rapid depletion without new carbon input. This was in line with the differences of the amounts of $\mathrm{Fe} / \mathrm{Al}-\mathrm{OC}$. It 
indicated that the carbohydrate was quick in response to the $\mathrm{C}$ changes of Fe/Al-OC. However, the phenol- $\mathrm{C}$ of Fe/ $\mathrm{Al}-\mathrm{OC}$ was protected well. Conversely, the $\mathrm{C}-\mathrm{O}$ groups of polysaccharides of $\mathrm{Fe} / \mathrm{Al}-\mathrm{OC}$ did not remain steadily during the decomposition of maize straw. A number of studies showed that the reaction between humus substances and iron oxides favored carbon sequestration in paddy soils [33, 34, 35]. Xie and Shang [36] observed that the functional quinone-phenol groups presented in humic substances might contribute to the complexed $\mathrm{Fe}(\mathrm{III})$ reduction. Moreover, the $\mathrm{Fe}(\mathrm{III}) / \mathrm{Fe}(\mathrm{II})$ redox couple in relation to oxidation and reduction of iron and humic substances had been described in detail [37-40].

Possibly, the $\mathrm{Fe} / \mathrm{Al}-\mathrm{OC}$ was protected by phenol groups against further degradation. In this study, the results indicated that the phenol- $\mathrm{C}$ was more stable than polysaccharide-C. Rumpel et al. [41] considered that microbial-derived polysaccharides were most likely stabilized preferentially by mineral interactions compared to plantderived polysaccharides. Because the polysaccharides were mainly derived from maize straw in this study, and the polysaccharides were not stable and decreased with time.

\section{Selective protection of hydrophilic organic matter}

The selective preservation of aliphatic- $C$ in humic acids had been demonstrated [3]. In this study, the absorbance peaks at about 2920 and $2850 \mathrm{~cm}^{-1}$ were not found. Possibly, the aliphatic- $\mathrm{C}$ was decreased during the purification process.

Proteins were showed by the band at $1666 \mathrm{~cm}^{-1}$ [42]. It was considered as one of the typical hydrophilic natural organic matters except polysaccharides and other monomeric biopolymer such as amino sugars [43]. The recalcitrance of proteins in humic substances was achieved by encapsulation into hydrophobic domains of humic substances. Proteinaceous moieties might be physically encapsulated within the aliphatic moieties of humic acids [44]. Protein groups of Fe/Al-OC did not show distinct changes for the investigated samples. Because of overall negative charge, acidic regions and hydrophobic mechanisms, proteins could establish interaction with cations [27].

\section{Conclusions}

With the help of FTIR spectroscopy, we were able to effectively identify the variation on the functional groups representing molecular structure of $\mathrm{Fe} / \mathrm{Al}-\mathrm{OC}$ during the decomposition of maize straw in soil. The results of FTIR spectroscopy showed that proportion of polysaccharide- $\mathrm{C}$ decreased with time, but the phenol- $\mathrm{C}$ tended to increase with time. These results indicate that polysaccharide groups of Fe/Al-OC mainly contribute to the sequestration of $\mathrm{Fe} / \mathrm{Al}-\mathrm{OC}$ during the primary decomposition stage of maize straw, and the phenol group was stable in different genesis of paddy soils. Both of the polysaccharides and phenol groups were important to $\mathrm{C}$ sequestration in paddy soils and marsh soil.

\section{Authors' contributions}

XS carried out the molecular genetic studies, participated in the sequence alignment and drafted the manuscript. LL and Jufeng Zheng participated in drafting the manuscript. XZ and JZ carried out the molecular genetic studies. QH participated in drafting the manuscript. GP conceived of this study, participated in its design and help draft the manuscript. All authors read and approved the final manuscript.

\section{Acknowledgements}

This study was supported by Grants from the project of national natural science foundation of China (No. 40710019002). Thanks to Dr. Zeming Qi and Chengxiang Li for the work of FTIR spectroscopy test that was supported and finished at the infrared and far infrared station, National Synchrotron Radiation Laboratory (NSRL).

\section{Competing interests}

The authors declare that they have no competing interests.

Received: 29 August 2015 Accepted: 4 April 2016

Published online: 18 August 2016

References

1. González-Estrada E, Rodriguez LC, Walen VK, Naab JB, Koo J, Jones JW, Herrero M, Thornton PK. Carbon sequestration and farm income in West Africa: identifying best management practices for smallholder agricultural systems in northern Ghana. Ecol Econ. 2008;67:492-502.

2. Pan G, Li L, Zheng J, Zhang X, Zhou P. Perspective on cycling and sequestration of organic carbon in paddy soils of China. Acta Pedolo Sin. 2008:45:901-14 (in Chinese).

3. Spaccini R, Piccolo A. Molecular characteristics of humic acids extracted from compost at increasing maturity stages. Soil Biol Biochem. 2009:41:1164-72.

4. Zheng JF, Cheng K, Pan GX, Smith P, Li LQ, Zhang XH, Zheng JW, Han XJ, Du YL. Perspectives on studies on soil carbon stocks and the carbon sequestration potential of China. Chinese Sci Bull. 2011;56:3748-58.

5. Song XY, Li LQ, Zheng JF, Pan GX, Zhang XH, Zheng JW, Hussain Q, Han $X J$, Yu XY. Sequestration of maize crop straw $C$ in different soils: role of oxyhydrates in chemical binding and stabilization as recalcitrance. Chemosphere. 2012:87:649-54.

6. Henriksen TM, Breland TA. Carbon mineralization, fungal and bacterial growth and wnzyme activities as affected by contact crop residues and soil. Biol Fert Soil. 2002;35:41-8.

7. Soon YK, Arshad MA. Comparison of the decomposition and $\mathrm{N}$ and P mineralization of canola, pea and wheat residues. Biol Fert Soils. 2002;36:10-7.

8. Eneji $A E$, Honna T, Yamamoto S, Masuda T, Endo T, Irshad M. Changes in humic substances and phosphorus fractions during composting. Commun Soil Sci Plant Anal. 2003;34:2303-14.

9. Kumar K, Goh KM. Nitrogen release from crop residues and organic amendments as affected by biochemical composition. Commun Soil Sci Plant Anal. 2003;34:2440-1.

10. Mubarak AR, Rosenani AB. Soil organic matter fractions in humid tropics as influenced by application of crop residues. Commun Soil Sci Plant Anal. 2003:34:933-43.

11. Zibilske LM, Materon LA. Biochemical properties of decomposing cotton and corn stem and root residues. Soil Sci Soc Am J. 2005;69:378-86.

12. Wang L, Sun W, Yuan G, Ren F. Studies on paddy soils VII. The comparison of composition and nature of humus between two paddy soils of different origin. J Nanjing Agric Univ. 1986;62:62-8 (in Chinese). 
13. Spaccini R, Piccolo A, Conte P, Haberhauer G, Gerzabek MH. Increased soil organic carbon sequestration through hydrophobic protection by humic substances. Soil Biol Biochem. 2002;34:1839-51.

14. Zhang J, Dou S. Dynimic changes of humic acid and fulvic acid in ignited soil during corn stalk decomposition. J Jilin Agric Univ. 2002;24:60-4 (in Chinese)

15. Zhang J, Dou S. Dynamic change of humic acid and fulvic acid during corn stalk decomposition. Chin J Soil Sci. 2005;36:134-6 (in Chinese).

16. González Pérez M, Martin-Neto L, Saab SC, Novotny EH, Milori DMBP, Bagnato VS, Colnago LA, Melo WJ, Knicker H. Characterization of humic acids from a Brazilian Oxisol under different tillage systems by EPR, ${ }^{13} \mathrm{C}$ NMR, FTIR and fluorescence spectroscopy. Geoderma. 2004;118:181-90.

17. Schöning I, Morgenroth G, Kögel-Knabner I. O/N-alkyl and alkyl C are stabilised in fine particle size fractions of forest soils. Biogeochemistry. 2005;73:475-97.

18. Smernik RJ. Solid-state ${ }^{13} \mathrm{C}$ NMR spectroscopic studies of soil organic matter at two magnetic field strengths. Geoderma. 2005;125:249-71.

19. Artz RRE, Chapman SJ, Robertson AHJ, Potts JM, Défarge FL, Gogo S, Comont L, Disnar JR, Francez AJ. FTIR spectroscopy can be used as a screening tool for organic matter quality in regenerating cutover peatlands. Soil Biol Biochem. 2008;40:515-27.

20. Tatzber M, Stemmer M, Spiegel H, Katzlberger C, Haberhauer G, Mentler A, Gerzabek MH. FTIR-spectroscopic characterization of humic acids and humin fractions obtained by advanced $\mathrm{NaOH}, \mathrm{Na}_{4} \mathrm{P}_{2} \mathrm{O}_{7}$, and $\mathrm{Na}_{2} \mathrm{CO}_{3}$ extraction procedures. J Plant Nutr Soil Sci. 2007;170:522-9.

21. Zhou P, Piccolo A, Pan G, Daniela S. Soil enhancement in three major types of paddy soils in a long-term agro-ecosystem experiment in south China III. Structural variation of particulate organic matter of two paddy soils. Acta Pedol Sin. 2009;46:398-405.

22. Xu JM, Yuan KN. Dissolution and fractionation of calcium-bound and ironand aluminum-bound humus in soils. Pedosphere. 1993;3:75-80.

23. Lu RK. Methods of soil and agrochemical analysis. Beijing (in Chinese): China Agric Sci Technol Press; 2000.

24. Fuentes M, Baigorri R, Gonzalez-Gaitano G, García-Mina JM. The complementary use of ${ }^{1} \mathrm{H}$ NMR, ${ }^{13} \mathrm{C}$ NMR, FTIR and size exclusion chromatography to investigate the principal structural changes associated with composting of organic materials with diverse origin. Org Geochem. 2007;38:2012-23.

25. Solomon D, Lehmann J, Kinyangi J, Amelung W, Lobe I, Pell A, Riha S, Ngoze S, Verchot LOU, Mbugua D, Skjemstad JAN, Schäfer T. Long-term impacts of anthropogenic perturbations on dynamics and speciation of organic carbon in tropical forest and subtropical grassland ecosystems. Glob Change Biol. 2007;13:511-30.

26. González-Pérez M, Vidal Torrado P, Colnago LA, Martin-Neto L, Otero XL, Milori DMBP, Gomes FH. ${ }^{13} \mathrm{C}$ NMR and FTIR spectroscopy characterization of humic acids in spodosols under tropical rain forest in southeastern Brazil. Geoderma. 2008;146:425-33.

27. Shirshova LT, Ghabbour EA, Davies G. Spectroscopic characterization of humic acid fractions isolated from soil using different extraction procedures. Geoderma. 2006;133:204-16.

28. Solomon D, Lehmann J, Kinyangi J, Liang B, Schäer T. Carbon K-Edge NEXAFS and FTIR-ATR spectroscopic investigation of organic carbon speciation in soils. Soil Sci Soc Am J. 2005;69:107-19.
29. Xiao Y, Dou S. Study on infrared spectra of soil humus fractions. Chin J Anal Chem. 2007;35:1596-600.

30. Francioso O, Ciavatta C, Tuganoli V, Sanchez-Cortes S, Gessa C. Spectroscopic characterization of pyrophosphate incorporation during extraction of peat humic acids. Soil Sci Soc Am J. 1998;62:181-7.

31. He Z, Ohno T, Cade-Menun BJ, Erich MS, Honeycutt CW. Spectral and chemical characterization of phospates associated with humic substances. Soil Sci Soc Am J. 2006;70:1741-51.

32. Rulmont A, Cahay R, Liegeois-Duyckaerts M, Tarte P. Vibrational spectroscopy of phosphate: some general correlations between structure and spectra. Eur J Solid State Inorg Chem. 1991;28:207-19.

33. Zhou P, Song G, Pan G, Li L, Zhang X, Wu L. Soil enhancement in three major types of paddy soils in a long-term agro-ecosystem experiment in south China II. Chemical binding and protection in micro-aggregate size fractions. Acta Pedol Sin. 2009:46:263-73 (in Chinese).

34. Sun W, Wang L, Zhu K. Studies on paddy soils VIII. Humus and complex iron in alluvial paddy soils of Jiangsu hill region. J Nanjing Agric Univ. 1987;3:74-9 (in Chinese)

35. Maie N, Watanabe A, Kimura M. Chemical characteristics and potential source of fulvic acids leached from the plow layer of paddy soil. Geoderma. 2004;120:309-23.

36. Xie L, Shang C. Role of humic acid and quinone model compounds in bromate reduction by zerovalent iron. Environ Sci Technol. 2005;39:1092-100.

37. Stryuyk C, Sposito G. Redox properties of standard humic acids. Geoderma. 2001;102:329-46.

38. Pullin MJ, Cabaniss SE. The effects of $\mathrm{pH}$, ionic strength, and iron-fulvic acid interactions on the kinetics of nonpotochemical iron transformations I. Iron(II) oxidation and iron(III) colloid formation. Geochim Cosmochim Acta. 2003;67:4067-77.

39. Pullin MJ, Cabaniss SE. The effects of $\mathrm{pH}$, ionic strength, and iron-fulvic acid interaction on the kinetics of nonphotochemical iron transformations. II. The kinetics of thermal reduction. Geochim Cosmochim Acta. 2003;67:4079-89.

40. Xie L, Shang C, Zhou Q. Effect of Fe(III) on the bromate reduction by humic substances in aqueous solution. J Environ Sci. 2008;20:257-61.

41. Rumpel C, Eusterhues K, Kogel-Knabner I. Non-cellulosic neutral sugar contribution to mineral associated organic matter in top- and subsoil horizons of two acid forest soils. Soil Biol Biochem. 2010;42:379-82.

42. Mecozzi M, Pietrantonio E. Carbohydrates proteins and lipids in fulvic and humic acids of sediments and its relationships with mucilaginous aggregates in the Italian seas. Mar Chem. 2006;101:27-39.

43. Zularisam AW, Ismail AF, Salim MR, Sakinah M, Hiroaki O. Fabrication, fouling and foulant analyses of asymmetric polysulfone (PSF) ultrafiltration membrane fouled with natural organic matter (NOM) source waters. J Membr Sci. 2007;299:97-113.

44. Zang $X$, van Heemst JDH, Dria KJ, Hatcher PG. Encapsulation of protein in humic acid from a histosol as an explanation for the occurrence of organic nitrogen in soil and sediment. Org Geochem. 2000;31:679-95.

\section{Submit your manuscript to a SpringerOpen ${ }^{\circ}$ journal and benefit from:}

- Convenient online submission

- Rigorous peer review

- Immediate publication on acceptance

- Open access: articles freely available online

- High visibility within the field

- Retaining the copyright to your article

Submit your next manuscript at springeropen.com 